\title{
Fra retningslinjer til god praksis - hvordan sikre kvaliteten på selvmordsrisikovurderinger i journalene?
}

Ved Ewa Ness

\author{
Nå er de nasjonale retningslinjene for forebygging av selvmord i psykisk helsevern \\ endelig kommet. Nå starter implementeringen, men hvordan omsette retningslinjer \\ til klinisk praksis? Erfaringsmessig vet vi at det er et langt stykke fra å være enige \\ om retningslinjer til å etterleve dem i praksis. Artikkelen viser hvordan man med \\ enkle midler kan bedre journalkvaliteten i kliniske avdelinger.
}

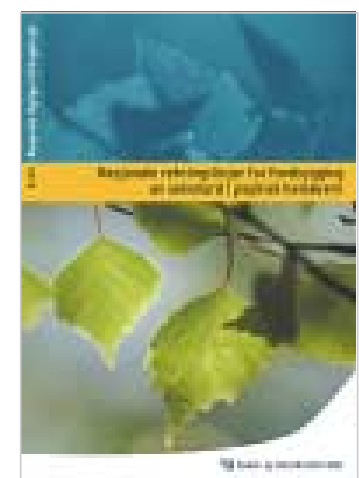

$M$ in første erfaring med kvalitetsarbeid var på begynnelsen av 1990-tallet da jeg arbeidet som assistentlege. A vdelingen hadde hatt tilsyn fra fylkeslegen og flere avvik var påpekt. A vdelingsoverlegen ønsket seg en håndbok der faglige retningslinjer skulle beskrives, og jeg tok på meg oppgaven å lede dette arbeidet uten å vite hva jeg bega meg utpå.

Dette var et arbeid som det skulle vise seg tok flere år. Vi delte ut skriveoppgaver til de forskjellige kollegene. Da vi kom til høringsrunden, oppdaget vi at vi var mye mer faglig uenige enn vi hadde trodd. Det ble kraftige diskusjoner, og de faglige motsetningene blant kollegene kom tydelig fram. A rbeidet stoppet opp i mangel av beslutningsdyktighet, og ble liggende i flere år før vi med en kraftanstrengelse greide å fatte beslutninger. En lignende prosess gjentok seg senere ved en avdeling der jeg satte i gang med å lage håndbok.

Som ny leder av Psykiatrisk legevakt i O slo i 1996 innførte jeg retningslinjer for journal føring etter flere klager på journaldokumentasjon. Det medførte likevel ingen stor endring. Vi bestemte da at vi skulle sjekke kvaliteten på dokumentasjonen hos alle medarbeiderne gjennom å gjøre en revisjon. Vi kalte revisjonen for journalprosjektet.

Denne revisjonen ble varslet i god tid, og medarbeiderne ble oppfordret til å søke veiledning på sin journalskriving. Det var det kun én spesialsykepleier som gjorde.

R evisjonen ble gjennomført på grunnlag av journal notater skrevet av medarbeiderne - tre notater fra hver enkelt medarbeider. N otatene fra våre om lag 50 medarbeidere ble anonymisert av sekretæren, og så vurdert av tre av fagpersonene i ledelsen, to psykiatere og en spesialsykepleier.

Det vi ønsket å undersøke var om retningslinjene for journalføring ble fulgt, og om journalene inneholdt en eksplisitt faglig vurdering av pasientens tilstand.
Vi tok utgangspunkt i journalforskriften (Forskrift om pasientjournal, 2000) og en artikkel skrevet av Solberg og medarbeidere om journalkvalitet (1995): Journalen - innhold, forventninger og kvalitet. Forfatterne hadde gjennomgått 100 indremedisinske journaler og rangerte resultatene fra 1-5, der 4 og 5 var "ikke bestått". V i brukte skalaen 1-4 der 1 er "gullstjerne", 2 er bra, 3 akseptabelt og 4 ikke bestått. M edarbeidere som fikk gullstjerne ble veldig fornøyde, og prestasjonen ble publisert i vårt interne nyhetsbrev. En slik revisjon gjør medarbeidere trygge, og de som gjør det bra blir stolte av egen faglighet. Retningslinjene for journalføring var at alle journaler skulle skrives etter en mal der man brukte kategoriene Bakgrunn, A ktuelt, Status presens, Vurdering og Tiltak. D et ble gjort en skjønnsmessig vurdering av journalene hvorvidt kravene til journalføring var tilfredsstilt. Resultatet var at syv ansatte ikke bestod kravene til journal dokumentasjon, og at bare $52 \%$ av alle journalene inneholdt en eksplisitt faglig vurdering. Vi var ikke helt fornøyde med dette resultatet. Vi besl uttet derfor å gjennomføre revisjon på journalkvalitet hver annet år. N å får alle nye medarbeidere veiledning på de journalene de fører på sine første tre vakter. M ange ledere tror nok at dersom de forteller sine medarbeidere hva de skal gjøre, så gjør de det. Slik er det ikke. Toyotafabrikken i Japan var av de aller første i verden som forstod betydningen av å sjekke kvaliteten regelmessig. H ensikten var å unngå feil, og oppnå et godt omdømme og et høyt bilsalg. K valitetssikring i bilproduksjon er ikke direkte overførbar til psykisk helsevern, men tenkningen omkring kvalitetssikring er det.

De fleste spesialister i psykiatri mener at de kan dokumentere en selvmordsrisikovurdering, men når vi tester om de faktisk kan det, kan en ofte bli overrasket over hvem det er som ikke består prøven.
Det er en kjent sak at de fleste mener at de kjører bil bedre enn gjennomsnittet. A merikanerne kaller det T he K nowing and Doing G ap - vi vet hva vi skal gjøre, men vi gjør det ikke. Det er her de fleste kvalitetsprosjekter kan gi gode resultater.

\section{Fagrevisjonen i 2005}

H else $\varnothing$ st RHF tok i 2005 initiativ til å gjøre en fagrevisjon innen tre fagfelt: medisin, kirurgi og psykisk helsevern. Innenfor psykisk helsevern ble selvmordsrisikovurderinger valgt som tema, og fem helseforetak ble invitert til å delta med hver sin spesialist i psykiatri. Disse fikk opplæring i revisjonsteknikk. Det ble så utarbeidet en sjekkliste som skulle brukes til å vurdere kvaliteten på selvmordsrisikovurderingene ved fem akuttpsykiatriske avdelinger. Det var liten uenighet i gruppen om utformingen av denne sjekklisten. Professor Lars M ehlum og jeg deltok som fageksperter.

Vi undersøkte kvaliteten på selvmordsrisikovurderingene som ble gjort ved innkomst på akuttav delingene når hovedproblemstillingen hos pasienten var suicidalitet. $M$ an skulle selvsagt tro at dette var en problemstilling som de akuttpsykiatriske avdelinger mestret i rimelig grad. $O$ verrasken de nok var det store forskjeller i resultatene. Ved to avdelinger var det ved innkomst utført en tilfredsstillende sel vmordsrisikovurdering hos mindre enn $50 \%$ av pasientene. A vdelingsoverlegene ved avdelingene var nok mest overrasket over dette resultatet. Selv var jeg mest av alt overrasket over at ingen av avdelingene noen gang hadde undersøkt disse forholdene tidligere.

For å vite at kvaliteten er god, må den sjekkes jevnlig. I tillegg må det være klare retningslinjer, og de ansatte må få opplæring og veiledning. 
Revisjonene ved Psykiatrisk legevakt har ført til at journalene er blitt kortere og mer fokuserte. Det betyr at de inneholder mer relevant informasjon en $n$ tidligere, og likevel er de kortere.

$M$ ange hevder at vi i dag bruker mer tid på dokumentasjon enn før. Jeg er ikke så sikker. Jeg husker hvor lange journalnotatene kunne være for 15 år siden; et innleggelsesskriv fra Psykiatrisk legevakt kunne være på tre håndskrevne A 4-sider, og det tok lang tid å skrive det for hånd. I dag dokumenterer vi oftere, men kortere. $\mathrm{N}$ å er innleggel sesskrivene fra Psykiatrisk legevakt vanligvis på en halv side.

\section{$\AA$ lære av andres feil}

En undersøkelse som ble publisert i Tidsskrift for Den norske legeforening (Rønneberg og W alby, 2008), viser at potensialet for å lære av feil brukesi liten grad når det skjer selvmord i tilknytning til behandling i psykisk helsevern. I mitt arbeid med kvalitetsforbedring har jeg vært opptatt av hvorfor vi ikke gjør det, og hvordan vi kan Iære mer av feilene.

O rganisasjonspsykologen $C$ hris A rgyris (1990) har skrevet mye om lærende organisasjoner; hva som kjennetegner dem og hva som skaper problemer i forhold til nødvendig endring. $\mathrm{H}$ an peker på at vi i for liten grad greier å være kritiske til andre, fordi vi er redde for å såre deres selvfølelse. Dette er det viktig å være klar over når man skal innføre for eksempel nye retningsl injer. Det er ikke nok at den enkelte tar ansvar for kvaliteten på eget arbeid, organisasjonen må også ta et ansvar. Det er vi i dag pålagt gjennom forskriften om internkontroll som er grundig behandlet i rundskrivet $\mathrm{H}$ vordan holde orden i eget hus (Sosial- og helsedirektoratet, 2004).

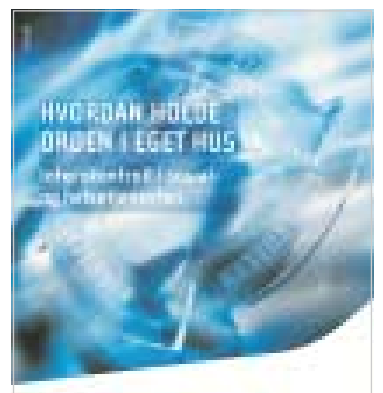

Innføring av faglig forsvarlige selvmordsrisikovurderinger:

- Bruk de nasjonale retningslinjene utgitt av Sosial- og helsedirektoratet (2008). Der følger det med prosedyrer som kan brukes direkte.

- Gi opplæring i retningslinjene til alle ansatte.

- Bruk mestersvennmodellen $\mathrm{i}$ opplæringen av nyansatte.

- Organiser veiledning på journaldokumentasjon til alle.

- Gjennomfør journalrevisjoner med jevne mellomrom, for eksempel en gang i året ved akuttavdelingene, inkludert personlig tilbakemelding til den enkelte lege.

- Sørgfor at alle behandlere diskuterer kritikk og klagesaker for å lære av feil.

Så hvordan skal vi legge til rette for en lærende organisasjon?

Ved Psykiatrisk legevakt publiserer vi alle klagesaker og kritikk fra fylkeslegen eller andre i vårt nyhetsbrev. M edarbeiderne vet dette, og det gjøres uten at pasient og behandlers navn oppgis, og på en måte som vi håper ikke bidrar til å skape syndebukker. Vi har aldri fått negative tilbakemeldinger på dette, tvert imot føler medarbeiderne seg trygge på at de vet hva som skjer også av negative hendelser. Fordelen er at alle kan lære av avvikene og kritikken, og slippe å gjøre feilene selv.

Erfaring med fem journal revisjoner ved Psykiatrisk legevakt har vist at det er selvmordsrisikovurderingene som fagfolkene har mest problemer med å dokumentere. A ndre psykiatriske vurderinger er det mindre problemer med. Derfor har vi satt inn mer ressurser, mer veiledning og mer opplæring på dette området, siden det er her vi kan påvise størst risiko for svikt.

\section{Myten "alle er like flinke"}

Erfaringene fra revisjonene viser at det er store individuelle forskjeller i kvaliteten på selvmordsrisikovurderinger. N oen skriver alltid gode vurderinger, mens andre får det ikke til, til tross for gjentatt veiledning og undervisning. Lederen må likevel sørge for at alle jobber faglig forsvarlig.

M an må bruke mest ressurser på de som trenger veiledning, og ikke like mye på alle. En slik revisjon gjør medarbeidere trygge, og de som gjør det bra blir stolte av egen faglighet.

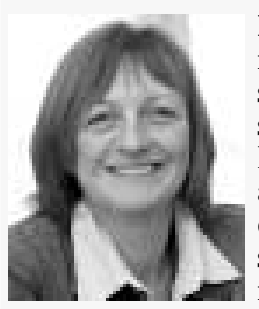

E wa $\mathbf{N}$ ess er psykiater og fagsjef v/Psykiatrisk divisjon U llevål universitetssykehus. Siden 1996 har hun vært leder for Psykiatrisk legevakt i Oslo. Hun er ansatt i en bistilling som seniorrådgiver v/SSFF med fokus på implementering av nye faglige retningslinjer for selvmordsforebygging i psykisk helsevern.

\section{Referanser}

A rgyris, C. (1990). O vercoming organizational defenses: facilitating organizational learning. $\mathrm{N}$ ew Jersey: Prentice $\mathrm{H}$ all.

Forskrift om internkontroll i sosial- og helsetjenesten. (2002). FO R-2002-12-20-1731. $\mathrm{H}$ else-og omsorgsdepartementet.

Forskrift om pasientjournal. (2000). FO R-200012-21-1385. H el se- og omsorgsdepartementet.

Rønneberg, U.\& W al by, F. A . (2008). Selvmord hos pasienter behandlet i psykisk helsevern. Tidsskrift for D en norske legeforening, 128, 180-3.

Solberg, E. E., A abakken, L., Bach-G ansmo, E., N ordby, G. \& Enger, E. (1995). Journalen: innhold, forventninger og kvalitet. Tidsskrift for Den norske lægeforening, 115, 488-9.

Sosial- og helsedirektoratet. (2008). N asjonale retningslinjer for forebygging av selvmord $i$ psykisk helsevern. (IS-1511/2008). 0 slo: Sosialog hel sedirektoratet.

Sosial- og helsedirektoratet. (2004). H vordan holde orden i eget hus: internkontroll i sosialog helsetjenesten. (IS-1183/2004). O slo: Sosialog helsedirektoratet.

\section{Anbefalt litteratur}

A rntzen, E. (2007). En forutsigbar helsetjeneste: kvalitet og orden i eget hus. O slo: G yldendal akademisk. Sosial- og helsedirektoratet. (2005).

... $0 \mathrm{~g}$ bedre skal det bli!: nasjonal strategi for kvalitetsforbedring i sosial- og helsetjenesten. (IS-1162/2005). O slo: Sosial- og helsedirektoratet. 